\title{
Fractures and ventilator dependence in neonates: is the use of bisphosphonates an appropriate consideration?
}

To the Editor,

Atraumatic or minimal trauma fractures are reported to occur in $1-10 \%$ of contemporary cohorts of very low birth weight infants (1-3). The effect of bisphosphonates in infants with severe metabolic bone disease of prematurity (MBDP) is unknown and untested, in terms of either fracture prevention or long-term safety.

Following an atraumatic oblique femoral fracture at 4 weeks corrected age, a 6 month old male infant (weight $3.5 \mathrm{~kg}$, 5th percentile) born at $24+2$ weeks gestation (birthweight $742 \mathrm{~g}, 51^{\text {st }}$ centile) was referred for consideration of bisphosphonate therapy as an adjunct to management of severe metabolic bone disease of prematurity. The neonatal course had been complicated by an ileal perforation requiring ileostomy and prolonged parenteral nutrition, as well as severe chronic lung disease requiring four courses of corticosteroids. Osteopenia was evident on chest X-ray (without any radiological features of rickets) despite optimal enteric and parenteral calcium and phosphate supplementation during the preceding months, and an atraumatic femoral fracture had been noted at 5 months of age. At the time of initial review the infant remained mechanically ventilated after two failed attempts at extubation despite minimal ventilator requirements; one further extubation attempt was planned prior to consideration of palliation. It was postulated that in this instance, severe osteopenia of the ribcage had resulted in inadequate chest wall movement, thereby preventing normal respiratory function.

A literature review of the use of bisphosphonate therapy in MBDP did not identify any relevant studies upon which to inform clinical practice. However, given the end of life nature of the request, a decision was taken to trial this therapy in an effort to improve chest wall function. A single low dose of Zoledronic acid (the bisphosphonate in routine clinical use at our centre, $0.02 \mathrm{mg} / \mathrm{kg}=0.07 \mathrm{mg}$ dose) was intravenously administered and was well tolerated; a $50 \%$ reduction of the standard $0.04 \mathrm{mg} / \mathrm{kg}$ was chosen in order to reduce the risk of potential side effects such as an acute phase reaction or This is the author manuscript accepted for publication and has undergone full peer review but has not been through the copyediting, typesetting, pagination and proofreading process, which may lead to differences between this version and the Version of Record. Please cite this article as doi: $10.1111 /$ jpc. 13348

This article is protected by copyright. All rights reserved. 
hypocalcaemia which may have adversely impacted on respiratory function. Successful extubation to non-invasive ventilator support occurred one week following bisphosphonate administration. Serum alkaline phosphatase (ALP) decreased from 2190IU/I to 1094 IU/I (normal range 100-350) during this timeframe, Table 1. No assessments of the urinary excretion or reabsorption of calcium or phosphate were undertaken. In the four months following bisphosphonate infusion, ALP remained above the reference range with an elevated parathyroid hormone level indicating ongoing metabolic bone disease. No further bisphosphonate therapy has been administered to date, no further fractures have occurred and the infant remains oxygen free at 3 years of age.

The pathophysiology of MBDP is complex but is largely the result of inadequate mineral ion nutrition in the ex-utero preterm environment (4). Increased awareness of this entity and improvements in mineral supplementation for premature infants have led to reductions in the severity of MBDP and rates of the associated fractures in recent decades $(3,5)$ However, a relative dietary deficiency of phosphate and calcium may still occur in preterm infants with multiple co-morbidities resulting in secondary hyperparathyroidism which in turn leads to increased bone resorption and poor bone mineralisation This is the first known published report of the use of bisphosphonate therapy for the management of metabolic bone disease of prematurity where successful extubation was temporally related to the administration of a single dose of zoledronic acid. Potential mechanisms which have been postulated for this positive outcome include pain reduction allowing more efficient chest wall movement or direct strengthening of the thoracic cage. The authors caution that clinical trials are warranted prior to its more widespread use but, in exceptional circumstances for those infants with severe metabolic bone disease and ventilator dependence, intravenous bisphosphonates may be considered as an adjunctive therapy. However this should not replace adequate supplementation of phosphate, calcium and vitamin $\mathrm{D}$, which remains the mainstay of treatment for the prevention and management of MBDP and fractures in the preterm population(6).

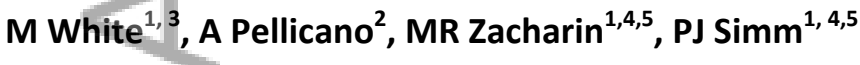


${ }^{1}$ Departments of Endocrinology \& Diabetes and ${ }^{2}$ Neonatology, The Royal Children's Hospital, Melbourne, Australia; ${ }^{3}$ Department of Paediatric and Adolescent Endocrinology and Diabetes, Monash Children's Hospital, Clayton, Australia; ${ }^{4}$ Murdoch Childrens Research Institute, Parkville, Australia; ${ }^{5}$ Department of Paediatrics, University of Melbourne, Australia

\section{References}

1. Amir J, Katz K, Grunebaum M, Yosipovich Z, Wielunsky E, Reisner SH. Fractures in premature infants. J Pediatr Orthop. 1988;8(1):41-4.

2. Lucas-Herald A, Butler S, Mactier H, McDevitt H, Young D, Ahmed SF. Prevalence and characteristics of rib fractures in ex-preterm infants. Pediatrics. 2012;130(6):1116-9.

3. Wei C, Stevens J, Harrison S, Mott A, Warner J. Fractures in a tertiary Neonatal Intensive Care Unit in Wales. Acta Paediatr. 2012;101(6):587-90.

4. Cooper C, Westlake S, Harvey N, Javaid K, Dennison E, Hanson M. Review: developmental origins of osteoporotic fracture. Osteoporosis international : a journal established as result of cooperation between the European Foundation for Osteoporosis and the National Osteoporosis Foundation of the USA. 2006;17(3):337-47.

5. Lyon AJ, McIntosh N, Wheeler K, Williams JE. Radiological rickets in extremely low birthweight infants. Pediatric radiology. 1987;17(1):56-8.

6. Harrison CM, Gibson AT. Osteopenia in preterm infants. Archives of disease in childhood Fetal and neonatal edition. 2013;98(3):F272-5. 
Table 1. Clinical and biochemical course pre- and post-bisphosphonate infusion

\begin{tabular}{|c|c|c|c|c|c|c|c|c|c|c|}
\hline$=$ & Normal range & Day -5 & Day 0 & Day +3 & Day +4 & Day +6 & Day +10 & Day +20 & Month +1 & Month +4 \\
\hline Ventilation Status $^{\dagger}$ & - & SIMV/TTV & SIMV/TTV & HFJV & HFJV & $\begin{array}{l}\text { Extubated } \\
\text { to CPAP }\end{array}$ & CPAP & NCPAP & NCPAP & $\begin{array}{l}\text { Low flow } \\
\text { nasal oxygen }\end{array}$ \\
\hline Ventilation settings & - & $21 / 8$ & $21 / 8$ & $20 / 6$ & $18 / 6$ & 11 & 11 & 8 & 8 & - \\
\hline $\mathrm{FiO}_{2}(\%)$ & - & 21 & 35 & 40 & 38 & 25 & 22 & 21 & 21 & $0.4 \mathrm{l} / \mathrm{min}$ \\
\hline Calcium & $1.9-2.7 \mathrm{mmol} / \mathrm{l}$ & 2.2 & 2.04 & 1.57 & 1.57 & - & 2.04 & 2.21 & 1.99 & 2.07 \\
\hline Corrected Calcium & $1.9-2.7 \mathrm{mmol} / \mathrm{l}$ & 2.34 & - & 1.81 & - & - & 2.1 & 2.39 & 2.15 & 1.95 \\
\hline Magnesium & 0.7-1.2mmol/I & 0.91 & 0.79 & 0.73 & 0.77 & - & 0.81 & 0.86 & 0.82 & 0.94 \\
\hline Phosphat & $1.3-2.3 \mathrm{mmol} / \mathrm{l}$ & 1.37 & 1.44 & 1.05 & 1.01 & - & 1.45 & 1.05 & 1.74 & 1.72 \\
\hline Albumin & $29-45 \mathrm{~g} / \mathrm{l}$ & 33 & - & 28 & 28 & - & 37 & 31 & 32 & 46 \\
\hline ALP & $100-350 \mathrm{IU} / \mathrm{I}$ & 2190 & - & 1229 & 1094 & - & 1168 & 1484 & 941 & 854 \\
\hline PTH & $1.3-6.8 \mathrm{pmol} / \mathrm{l}$ & 11.2 & - & - & - & - & - & - & - & 52.6 \\
\hline Vitamin D & $50-160 \mathrm{nmol} / \mathrm{I}$ & 67 & - & - & - & - & 67 & - & - & 59 \\
\hline
\end{tabular}

$\mathrm{FiO}_{2}$ : Fraction of inspired oxygen; ALP: Alkaline phosphatase; PTH: Parathyroid hormone; SIMV: Synchronised intermittent mandatory ventilation;

TTV: Targeted tidal volume; HFJV: High frequency jet ventilation; CPAP: Continuous positive airway pressure; NCAP: Nasal CPAP

${ }^{\dagger}$ Ventilator settings refer to peak inspiratory pressure(PIP)/positive end-expiratory pressure (PEEP) for SIMV/HFJV, and PEEP for CPAP/NCPAP

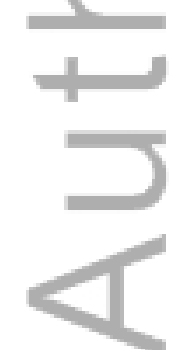

This article is protected by copyright. All rights reserved. 


\section{University Library}

\section{- M M N E R VA A gateway to Melbourne's research publications}

Minerva Access is the Institutional Repository of The University of Melbourne

Author/s:

White, M;Pellicano, A;Zacharin, MR;Simm, PJ

Title:

FRACTURES AND VENTILATOR DEPENDENCE IN NEONATES: IS THE USE OF BISPHOSPHONATES AN APPROPRIATE CONSIDERATION?

Date:

2016-11-01

Citation:

White, M., Pellicano, A., Zacharin, M. R. \& Simm, P. J. (2016). FRACTURES AND VENTILATOR DEPENDENCE IN NEONATES: IS THE USE OF BISPHOSPHONATES AN APPROPRIATE CONSIDERATION?. JOURNAL OF PAEDIATRICS AND CHILD HEALTH, 52 (11), pp.1042-1044. https://doi.org/10.1111/jpc.13348.

Persistent Link:

http://hdl.handle.net/11343/291906 